\title{
Evidence for Unusually Strong Near-field Ground Motion on the Hanging Wall of the San Fernando Fault during the 1971 Earthquake
}

\section{Clarence R. Allen}

Seismological Laboratory, California Institute of Technology

\section{James N. Brune}

Seismological Laboratory, University of Nevada at Reno

\section{Lloyd S. Cluff}

Pacific Gas and Electric Company

\section{Allan G. Barrows, Jr. \\ California Division of Mines and Geology}

\section{INTRODUCTION}

Reports of unusually intense ground motions in the very near fields of faults that have ruptured during earthquakes are becoming more common, particularly with the markedly increased worldwide strong-motion instrumentation in recent years (e.g., Heaton and Wald, 1994). The reported ground motions are sufficiently strong to have significant potential engineering impact (Hall et al., 1995). In addition to fault proximity, two other factors that have contributed to unusually high strong motions are rupture directivity (e.g., Somerville et al., 1997) and locations on the hanging walls of thrust faults (e.g., Nason, 1973; Abrahamson and Somerville, 1996; Brune, 1996a; Brune, 1996b). Perhaps nowhere has the sharp distinction between damage on the hanging wall and footwall of a thrust fault been more dramatically documented than during the 1945 Mikawa earthquake, Japan (Iida, 1985). Earlier reports of anomalous strong nearfield vertical acceleration, such as those of Oldham (1899) describing the great 1897 Assam earthquake, have often heretofore been discounted or ignored, but they now look more reasonable in the light of recent well recorded events. One figure of Oldham's report was reproduced in Richter (1958, p. 51) and has resulted in considerable analysis and criticism relative to peak vertical accelerations (e.g., Bolt and Hansen, 1977). However, another section of Oldham's report, relating to horizontal ground velocities and displacements, is more important to the phenomenon reported herein and will be discussed later in detail. This second part of the report has been overlooked by most researchers.
We here describe an intriguing phenomenon which satisfied all of the above three criteria (near field, directivity, and hanging wall location) which occurred along the Tujunga segment of the San Fernando Fault during the $M_{L}=6.5$ San Fernando, California, earthquake of 9 February 1971. The fault rupture, which was of combined thrust and strike-slip displacement, crossed the grounds of the Blue Star Trailer Park near the mouth of Lopez Canyon (Figure 1) and displaced a $50 \mathrm{~m}$-long asphalt roadway in a manner suggestive of very high vertical accelerations and large amplirudes of associated rapid horizontal ground displacement. The locality was noted and photographed by Allen and Cluff a few days following the earthquake, and it was subsequently mapped and trenched by Barrows (1975) and his colleagues. The physics of the phenomenon, here and elsewhere, has been the subject of ongoing interest by Brune (1996), who suggested that this episode be more fully documented.

Earlier reports of unusually intense shaking during the San Fernando earthquake, particularly on the hanging wall of the fault, include descriptions of shattered earth on ridge crests (Nason, 1973; Barrows, 1975; Kahle, 1975) and the puzzling movements of a series of 6-ton wire spools close to the fault (Kamb et al., 1971).

\section{OBSERVATIONS}

The geologic and geophysical relationships relevant to the 1971 San Fernando earthquake have been described in detail, probably most completely in Oakeshott (1975). Just west of the mouth of Lopez Canyon (Figure 1), the western- 


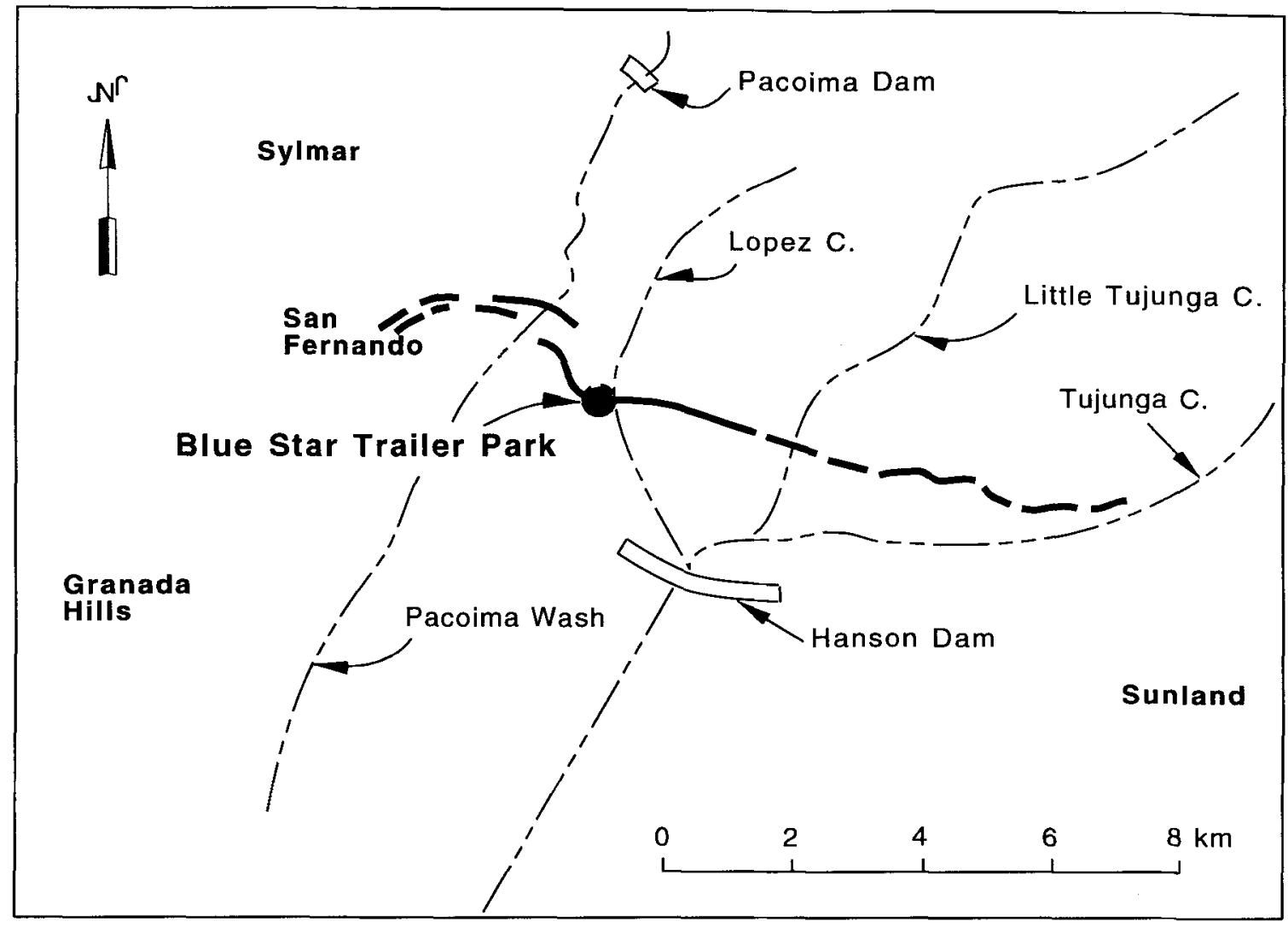

A Figure 1. Index map of the San Fernando earthquake area, showing the Blue Star Trailer Park locality near the mouth of Lopez Canyon. Heavy line is the surface trace of the San Fernando Fault.

most segment of the Tujunga segment of the San Fernando Fault passed through the Blue Star Trailer Park, which was founded on a series of excavated benches and near-vertical risers cut into the underlying Miocene Modelo formation. The horizontal benches were mostly covered by concrete trailer pads and asphalt roads and driveways. One of these asphalt roads (Figure 2) was cut by the fault at an angle of about $45^{\circ}$, leaving the asphalt-draped scarp, about $0.5 \mathrm{~m}$ high, shown in Figure 3. The locality is now buried by a roadfill for the extension of Paxton Street north of Foothill Boulevard.

The quandary presented by Figure 3 is that, although the asphalt slab is relatively unbroken and unrumpled, the pipe railing along the southeast side of the road can be seen in the photograph (right) to be broken and deformed, representing shortening by an estimated $1.2 \mathrm{~m}$ (Barrows, 1975). But this shortening occurred over the same interval in which the asphalt clearly shows no such shortening. Underlying the asphalt, the 1971 rupture is represented by two breaks about $0.7 \mathrm{~m}$ apart, although the upper (main) break flattens surfaceward so that both breaks intersect the ground surface near the base of the scarp. This is known from relationships exposed in a trench subsequently excavated only a few meters northwest (left) of the camera position (Figure 4), and also from good exposures on a near-vertical face just to the southeast (right) of the camera position, where the pre-earthquake rock facing collapsed. The 1971 faults here dipped about $30^{\circ}$ northeast (away from the camera), except very close to the surface, which is consistent with measurements elsewhere along the San Fernando Fault. Independent estimates of the horizontal shortening across the scarp in this vicinity were $1.4 \mathrm{~m}$ and $2.0 \mathrm{~m}$ by Sharp (1975) and $1.0 \mathrm{~m}$ by Kamb et al. (1971). These estimates were based on offsets of features other than the pipe railing.

How can the absence of horizontal shortening of the asphalt slab here be explained? There was no significant deformation of the asphalt on the footwall side of the scarp (i.e., behind the camera position of Figure 3). But it surprisingly turned out that $50 \mathrm{~m}$ northeast of the scarp, near the tree in the background of Figure 3, the same asphalt slab was "overthrust" relatively northeastward about $1.75 \mathrm{~m}$ over the asphalt slab of a perpendicular road (Figure 5). Thus, it seems that the entire $50 \mathrm{~m}$-long by $6 \mathrm{~m}$-wide asphalt slab, of estimated $5 \mathrm{~cm}$ thickness, was translated from the rear (i.e., from the area of the scarp) and essentially moved as a coherent unit 1 to $2 \mathrm{~m}$ relatively northeastward. The physics of this process may at first seem to be a real puzzle. It's a bit analogous to the problem of trying to push a tablecloth across a long table solely by pushing at one end. The frictional resistance simply does not allow it, and instead the tablecloth simply rumples near where one is pushing it. As 


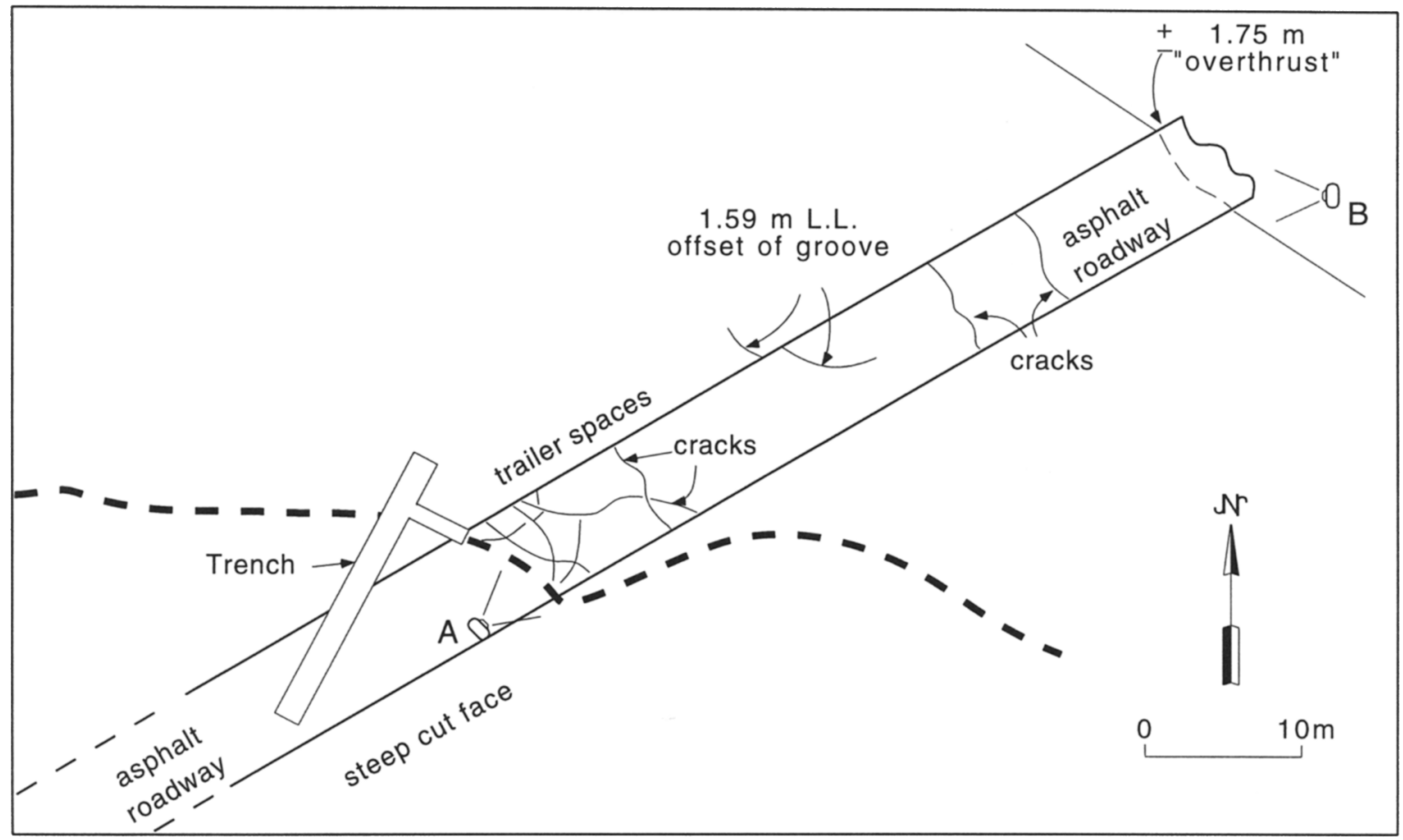

A Figure 2. Detailed map of the displaced asphalt slab (heavy solid line), simplified from the map of F. H. Weber, Jr., in Barrows (1975, pl. 4). Heavy dashed line is at the base of the 1971 scarp. Points "A" and "B" are, respectively, the camera locations of Figures 3 and 5.

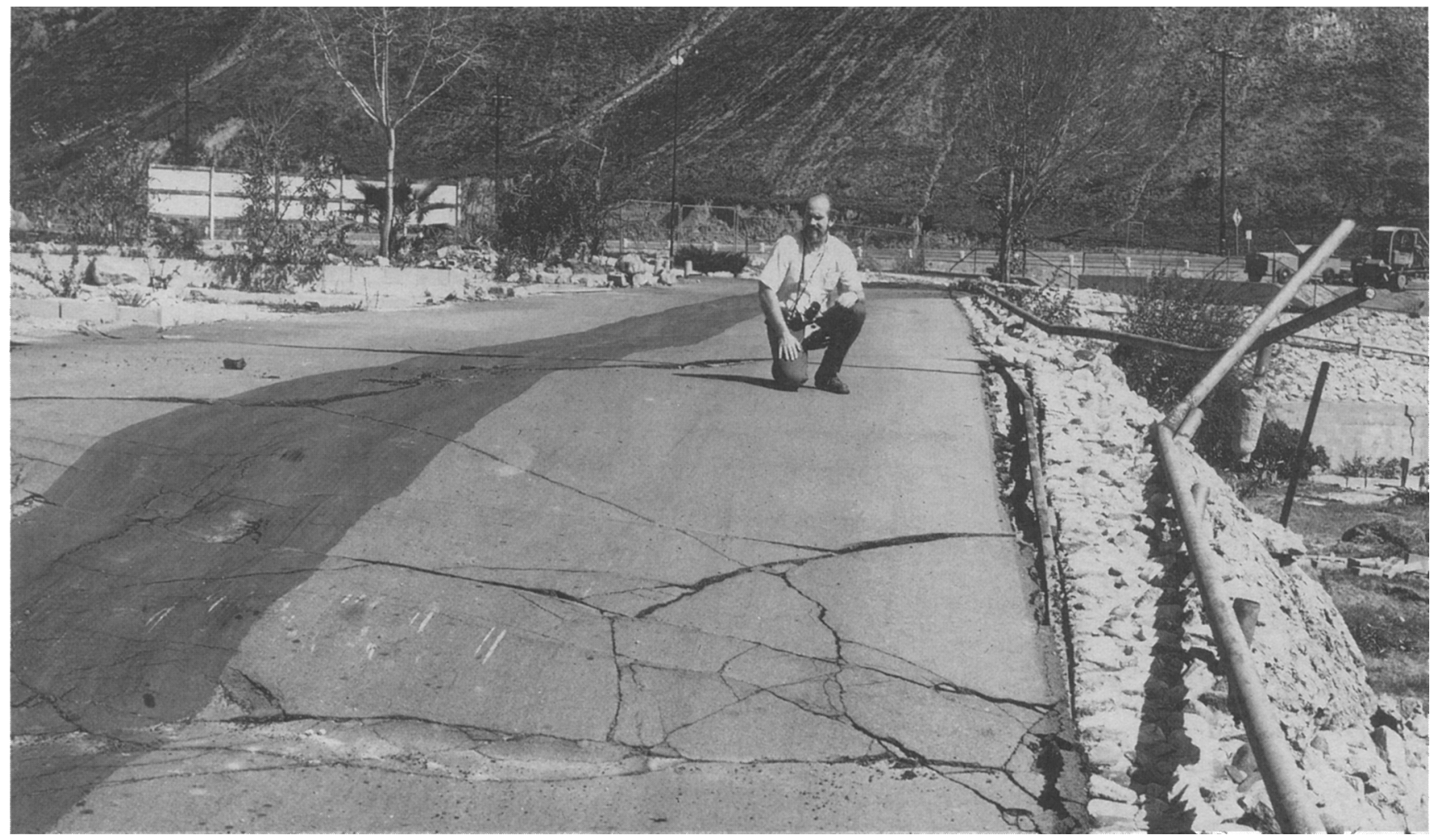

$\Delta$ Figure 3. View northeast from point "A" in Figure 2. Scarp is about $0.5 \mathrm{~m}$ high. Note bent and broken pipe at right, which was formerly a straight railing along the edge of the road (as in the background) but was shortened about $1.2 \mathrm{~m}$ by movement on the fault, which intersected the ground surface near the base of the scarp. Note that the asphalt shows no such shortening here. Photo by C. R. Allen. 


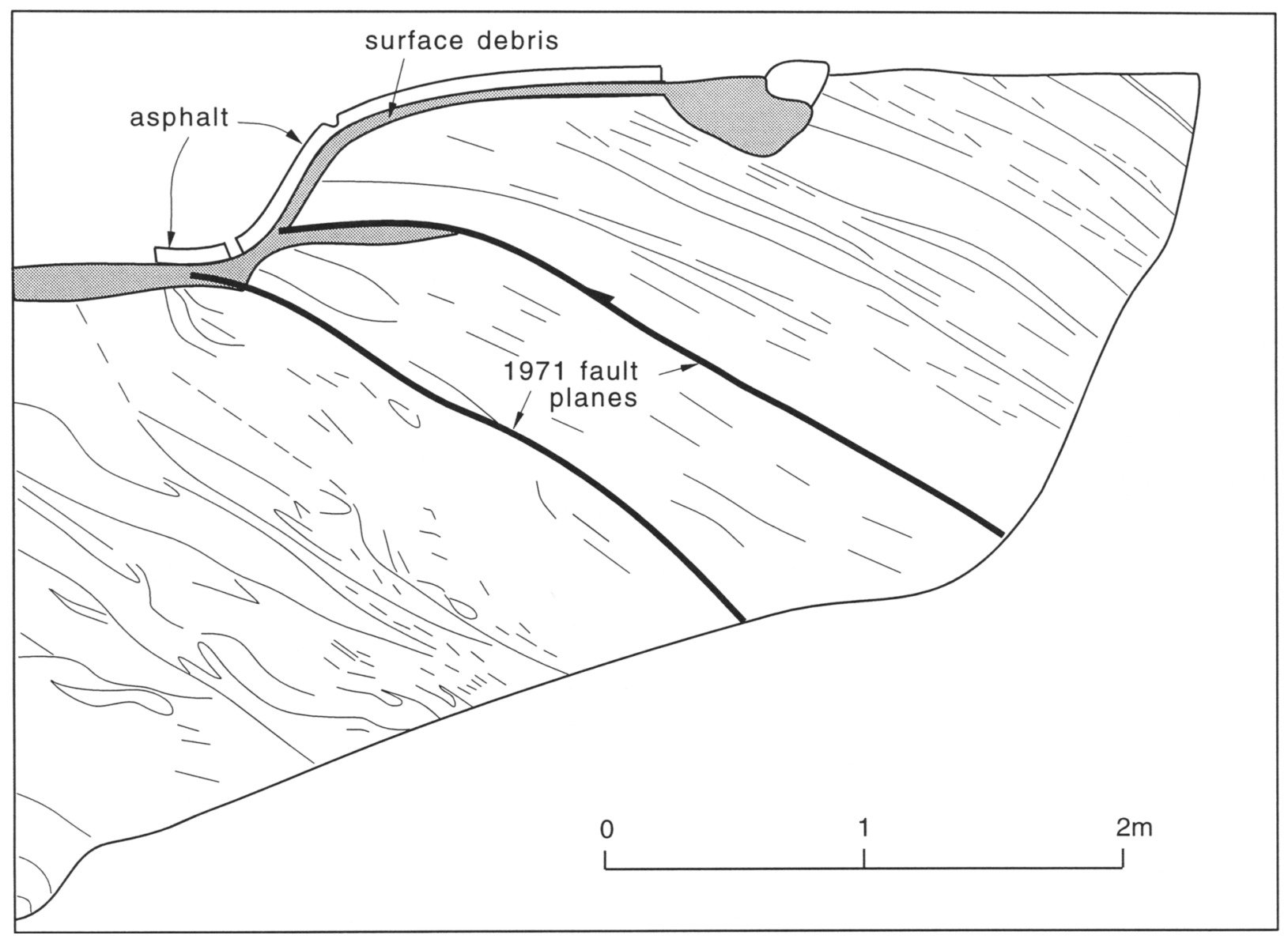

$\Delta$ Figure 4. Cross-section of the fault and scarp in trench excavated near the locality of Figure 3 . See Figure 2 for exact location and orientation. Heavy lines show 1971 breaks. Simplified from the trench log by A. G. Barrows and J. E. Kehle in Barrows (1975, pl. 4).

we discuss later, the phenomenon appears less puzzling when recent phenomena occurring at the hanging-wall toes of thrust faults are considered.

Several other observations are relevant. About midway along the length of the displaced slab, on its northwestern margin, a well delineated pre-earthquake groove that crossed the slab margin nearly at right angles was clearly offset leftlaterally $1.59 \mathrm{~m}$ (Figure 2) (Barrows, 1975). This is the most precise and nondebatable measurement anywhere of the slab offset. It's also interesting and coincidental that the fault displacement was a combination of thrust and left-lateral strike slip, so that the horizontal component of the motion vector (i.e., its bearing) was almost exactly parallel to the direction of the street, thus allowing the slab to move without having to force its way out of its constraining edges. Barrows (1975) estimates this direction as $\mathrm{N} 50^{\circ} \mathrm{E}$ from slicken sides exposed in the trench; Sharp (1975) reports N $55^{\circ} \mathrm{E}$ and N $56^{\circ} \mathrm{E}$; and Kamb et al. (1971) calculated $\mathrm{N} 61^{\circ} \mathrm{E}$ nearby. The road itself, as shown on F. H. Weber's map in Barrows (1975), trends N $59^{\circ} \mathrm{E}$, which was truly a fortuitous coincidence. Concerning the friction along the base of the asphalt slab, we can only report that the slab lay directly on the excavated and truncated upturned strata of mainly sandstones and siltstones of the Modelo formation, although the trench revealed pockets of surface debris that presumably remained from the original excavation process.

\section{INTERPRETATION}

In the years since 1971, numerous informal discussions have taken place attempting to explain the puzzling relationships described above. Hypothesized solutions tend to fall in to five categories:

(1) The observations are invalid, misinterpreted, or grossly exaggerated. We rule out this hypothesis on the basis of our own personal observations and the fact that many people inspected the locality with similar reactions. Furthermore, we feel that the photographs and maps speak for themselves.

(2) Frictional resistance to sliding along the interface of the asphalt slab and the underlying materials was substantially reduced in some way other than by vertical acceleration. Of relevance in this context are various mechanisms that have been proposed for landslide "lubrication." Liquefaction in the classical soil-mechanics sense can be ruled out here by the nature of the underlying materials and the substantial local depth of the water table. Movements of some landslides are 


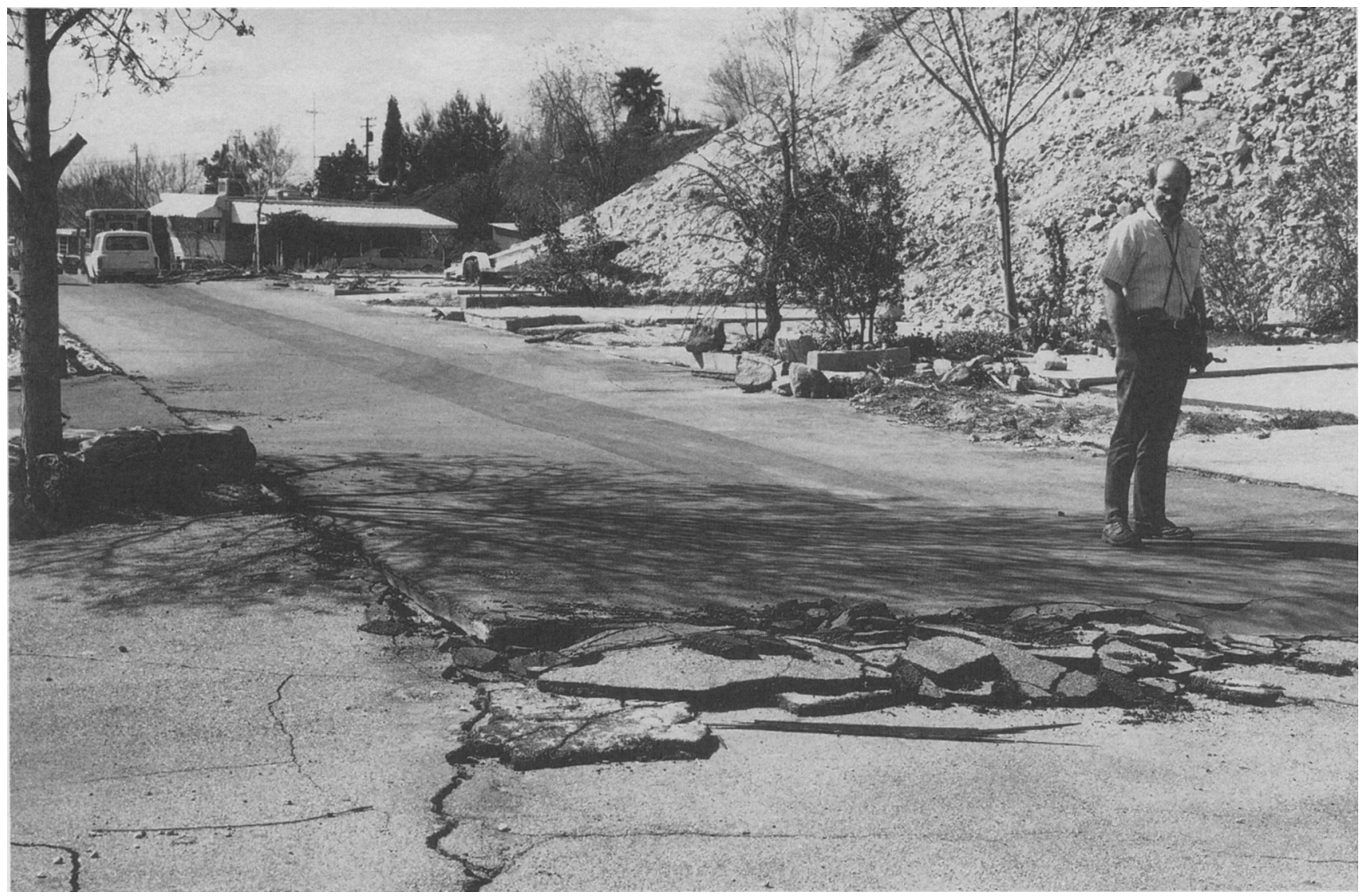

A Figure 5. View southwest from point "B" in Figure 2. Note "overthrust" of asphalt slab over asphalt of another driveway in the foreground, seemingly reflecting pushing of the coherent slab from the fault trace, $50 \mathrm{~m}$ in the distance. Amount of "overthrust" is about $1.75 \mathrm{~m}$. Note relatively uncracked and undeformed surface of most of the displaced slab. Photo by C. R. Aflen.

thought (albeit debatably) to have been enhanced by compressed air entrapped beneath the slide, such as was proposed for the prehistoric Blackhawk landslide in southern California and the 1964 Sherman Glacier slide, Alaska (Shreve, 1966, 1968). In any event, some sort of a "launching ramp" would be necessary to entrap the hypothesized great quantities of air beneath the slides, and there was no such opportunity for the feature described herein. Melosh $(1983,1996)$ has proposed that "acoustic fluidization" takes place beneath a sliding mass or along a fault, invoking a mechanism whereby the grossly reduced frictional resistance is related to random motions of particles within the acoustically fluidized debris. In our case, however, not only is there little particulate material to fluidize between the asphalt and the underlying sandstones, but the hypothesized required acoustical frequencies-in the $\mathrm{kHz}$ range-are far in excess of those normally associated with seismic shaking.

(3) A traveling "buckle" developed in the asphalt slab that served effectively to move it progressively forward. This hypothesis is analogous to moving a rug by abruptly lifting and lowering the rug at one end and allowing the resulting traveling wave to move the rug forward progressively (Figure 6). Weeks and Anderson (1958) postulated a similar mechanism for puz- zling overthrusts in very thin ice flows, related to wave action. A phenomenon similar to this occurs in foam rubber models of earthquakes (Brune et al., 1996) except that the upper plate is a very thick block supporting a dynamic wave. Also, when rubber slides over a rigid material, the motion is accomplished by a series of interface waves which separate the flexible block from the rigid block (Schallamach, 1971), but again, a thick overlying block would be required to propagate a dynamic wave.

For the case here, the forward motion can only be of the same order of magnitude as that of the wave amplitude, and the $\pm 1.5 \mathrm{~m}$ motion of the asphalt slab would require either a wave of unrealistic amplitude or a series of repeated individual traveling waves. More importantly, however, the asphalt slab was relatively rigid and some $5 \mathrm{~cm}$ thick-not easily deformed - and there were almost no cracks in most of the slab following the event (Figure 5).

(4) Under repeated high-frequency vertical accelerations, the slab moved forward by a "chattering" phenomenon. This hypothesis requires repeated high-frequency vertical accelerations approaching or exceeding $1 \mathrm{~g}$ that would permit the slab to move forward in a series of small increments, perhaps in a manner similar to the Schallamach waves described 


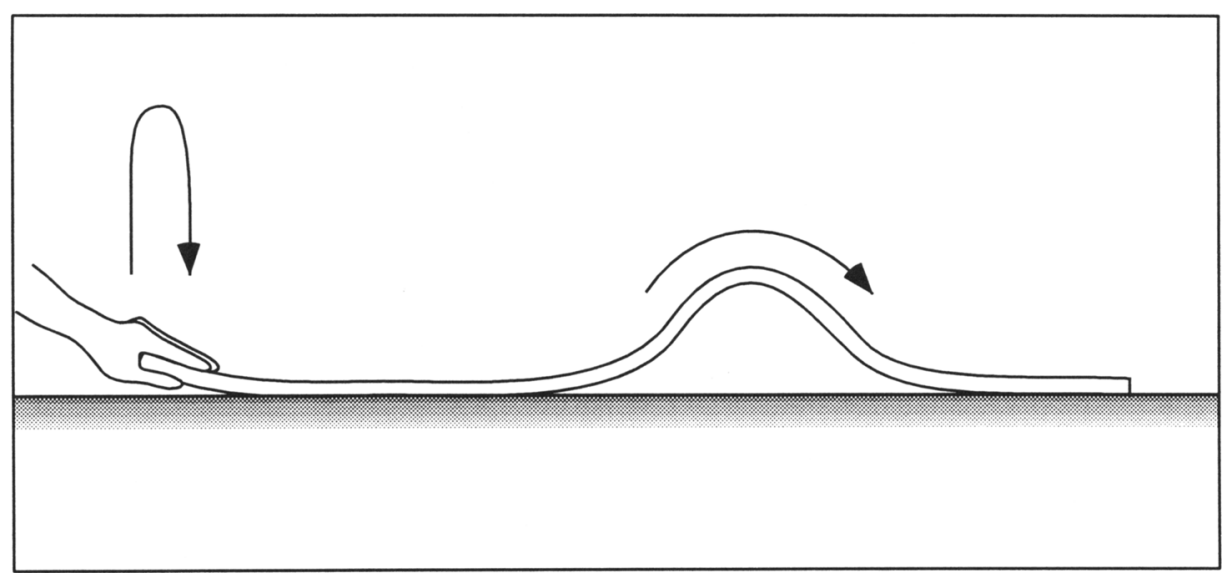

A Figure 6. Cartoon showing traveling-wave hypothesis for movement of the asphalt slab, analogous to moving a rug by shaking at one end.

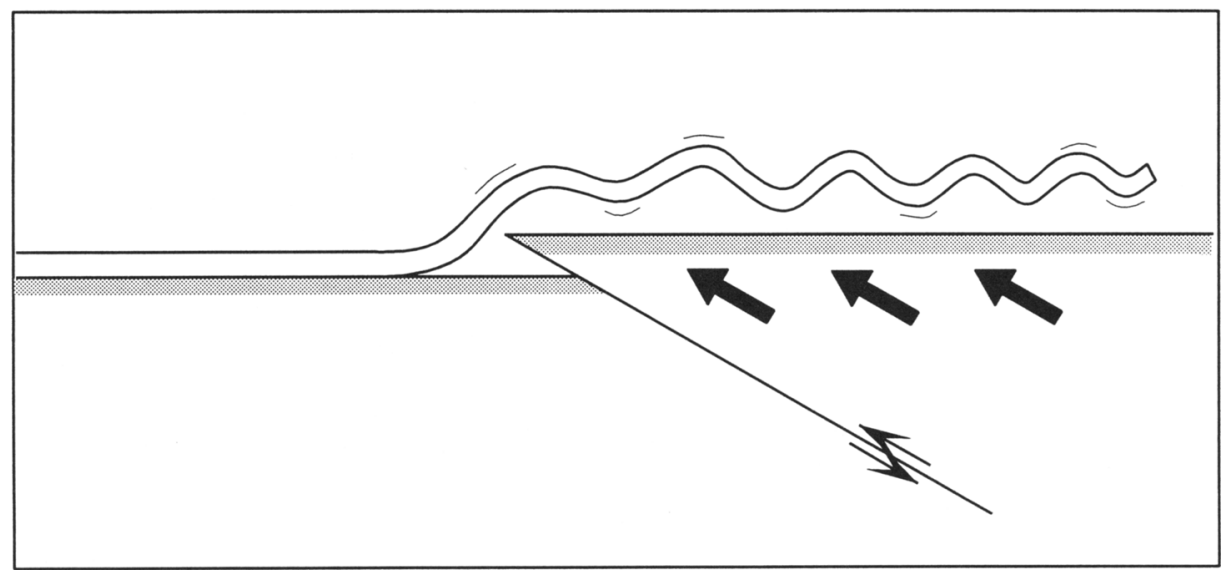

A Figure 7. Cartoon showing preferred hypothesis for slab movement. The entire slab was essentially thrown in the air as the ground moved rapidly beneath it by fault "fling" on the San Fernando Fault. Not to scale.

above. While we can't rule out such a phenomenon, we point out that the most impressive feature of the record from the nearest strong-motion seismometer on the hanging wall, 5 $\mathrm{km}$ north at Pacoima Dam, was not the intense short-period shaking, but instead the obvious long-period acceleration, velocity, and displacement pulse near the beginning of the record (Cloud and Hudson, 1975; Heaton, 1982). We suggest that this pulse increased in amplitude and strength significantly as it approached the narrowing tip of the hanging wall, causing a large near-surface fault "fling", and we thus prefer mechanism (5) below.

(5) The entire asphalt slab was essentially thrown off the ground by a long-period pulse with accelerations exceeding $1 \mathrm{~g}$, and during this short time interval the underlying rock moved about 1.5 $m$ relatively southwestward by displacement on the San Fernando Fault. This hypothesis (Figure 7), for which we argue herein, requires both that (1) there be a long-period pulse of high vertical acceleration, and that (2) the local fault displacement ("fling") take place very rapidly. The necessary long-period pulse, lasting at least $1 \mathrm{sec}$, has been mentioned above. There were no strong-motion instruments on the tip of the hanging wall during the San Fernando earthquake, but several records during subsequent worldwide earthquakes indicate that the hypothesis is realistic and that such motions are, in fact, to be expected, particularly showing strong velocity and displacement pulses. Figure 8 reproduces a drawing from Oldham (1899) showing clearly that during the Assam earthquake, large stone objects on a flat surface were catapulted a distance which Oldham calculates from trajectory theory required a minimum vertical acceleration of more than $1 \mathrm{~g}$ and a minimum horizontal velocity of about $300 \mathrm{~cm} / \mathrm{sec}$. Using the same trajectory theory, the asphalt slab observation suggests a minimum ground velocity of about $100 \mathrm{~cm} / \mathrm{sec}$, which is a value not unreasonable in the light of recent observations of ground-motion pulses. The Lucerne Valley record of the 1992 Landers earthquake showed such a strong near-field pulse, there horizontal, reflecting the strike-slip nature of the earthquake (Iwan and Chen, 1994). Likewise, the 1992 Erzincan, Turkey, earthquake was recorded in the very near field and showed a similar high-amplitude pulse (Joint Reconnaissance Team, 1992). As to the velocity of fault movement, both seismological analyses (e.g., Somerville et al., in press) and ground 


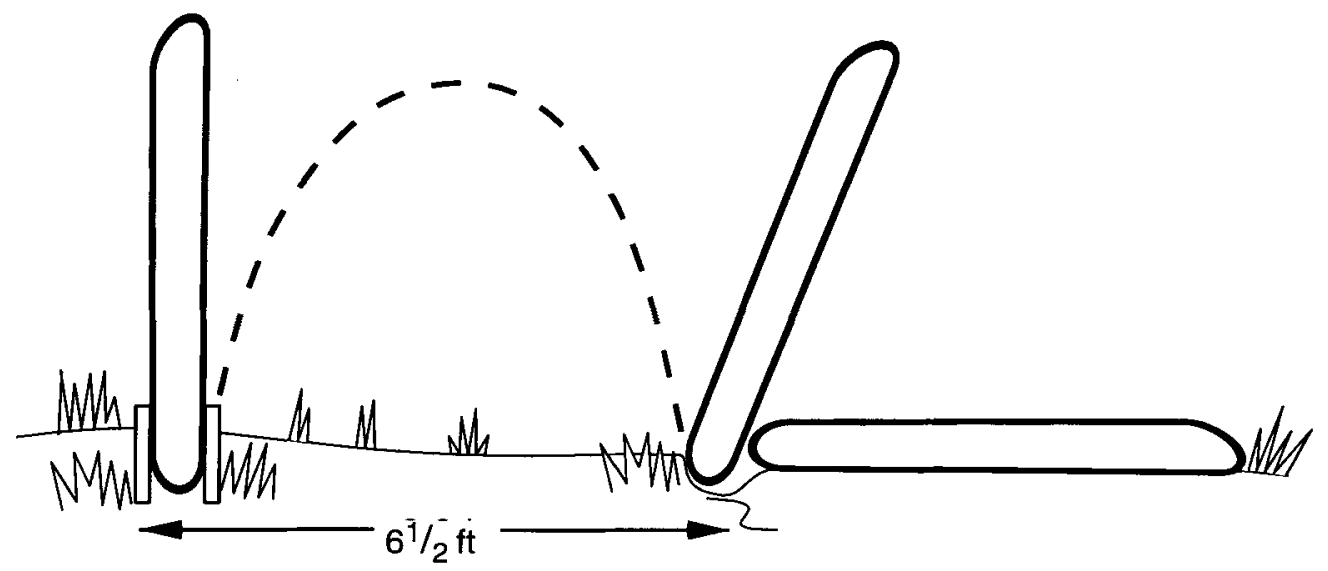

A Figure 8. Figure 14 of Oldham (1899), showing disturbance of Khasia monuments near Rambrai during 1897 Assam earthquake. Stone monument, about 6 feet high, was "shot upwards" and translated $61 / 2$ feel "to the place where a deep dent marked the spot at which its lower end had first struck the ground."

observations (e.g., Wallace, 1984; Yomogida and Nakata, 1994) indicate that large fault displacements can take place within a second or less. In analyzing the long-period records of fifteen recent earthquakes of $M_{W} 5.7$ to 7.2 , Somerville $e t$ al. (in press) find slip durations varying from 0.3 to $2.5 \mathrm{sec}$, averaging $1.1 \mathrm{sec}$.

A strong ground-motion pulse at the tip of thrust faults has been demonstrated in a foam-rubber model of thrust faulting (Brune, 1996), as well as in both lattice and finite element numerical models (Zeng et al., 1996; Oglesby et al., 1998; Shi et al., in press). Thus, our preferred explanation corresponds to a well documented physical phenomenon.

\section{CONCLUSIONS}

During the 1971 San Fernando earthquake, a $6 \mathrm{~m} \times 50 \mathrm{~m} \times$ $5 \mathrm{~cm}$ asphalt slab was seemingly translated coherently about $1.5 \mathrm{~m}$ by motions associated with thrust-fault displacement. The most likely explanation is that the slab was thrown off the ground by a strong long-period vertical acceleration pulse, during which time the ground rapidly (on the order of at least $100 \mathrm{~cm} / \mathrm{sec}$ ) moved relatively southeastward beneath it, associated with the "fling" of the San Fernando Fault at the narrowed tip of the hanging wall. The occurrence of such a phenomenon has been documented in physical models using foam rubber and in numerical models, and it was directly documented for the 1897 Assam, India earthquake. The engineering implications for structures built in similar environments may be significant.

\section{REFERENCES}

Abrahamson, N.A. and P.G. Somerville (1996). Effects of the hanging wall and footwall on ground motions recorded during the Northridge earthquake, Bull. Seism. Soc. Am. 86, S93-S99.

Barrows, A.G. (1975). Surface effects and related geology of the San Fernando earthquake in the foothills region between Little
Tujunga and Wilson Canyons, Calif. Div. Mines and Geol. Bull. 196, 97-117.

Bolt, B.A. and R.A. Hansen (1977). The upthrow of objects in earthquakes, Bull. Seism. Soc. Am. 67, 1415-1427.

Brune, J.N. (1996a). Particle motions in a physical model of shallow thrust faulting, Proc. Indian Acad. Sci., Earth and Plan. Sci. 105, L197-L206.

Brune, J.N. (1996b). Particle motion in a foam rubber model of thrust faulting [abstract], Seism. Res. Lett. 67(2), 34.

Brune, J.N., S. Brown, and P.A. Johnson (1993). Rupture mechanism and interface separation in foam rubber models of earthquakes: $A$ possible solution to the heat flow paradox and the paradox of large overthrusts, Tectonopyhysics 218, 59-67.

Cloud, W.K. and D.E. Hudson (1975). Strong motion data from the San Fernando, California, earthquake of February 9, 1971, Calif. Div. Mines and Geol. Bull. 196, 273-303.

Hall, J.F., T.H. Heaton, M.W. Halling, and D.J. Wald (1995). Nearsource ground motion and its effect on flexible buildings, Earthquake Spectra 11, 569-605.

Heaton, T.H. (1982). The 1971 San Fernando earthquake: A double event?, Bull. Seism. Soc. Am. 72, 2037-2062.

Heaton, T.H. and D. Wald (1994). Strong ground motions from the Northridge earthquake: Were they anomalous or a warning of things to come?, Eos, Trans. Am. Geophys. U. 75(44), Supp., 175.

Iida, K. (1985). Damage and intensity distribution of the January 13, 1945 Mikawa earthquake [in Japanese], in History and Damage by Earthquakes and Tsunamis in the Tokai District: Selected Scientific Papers of Prof. Kumiji Iida, Disaster Prevention Res. Lab., Fac. Eng., Aichi Eng. Univ., 570-668.

Iwan, W.D. and X. Chen (1994). Important near-field ground motion data from the Landers earthquake, Proc. 10th European Conf. Earthquake Eng., Vienna.

Joint Reconnaissance Team of Architectural Institute of Japan, Japan Society of Civil Engineers, and Bogazici University, Istanbul, Turkey (1992). Damage Report on 1992 Erzincan Earthquake, Turkey, Tokyo, Architectural Inst. of Japan.

Kamb, W.B., L.T. Silver, M.J. Abrams, B.A, Carter, T.H. Jordan, and J.B. Minster (1971). Pattern of faulting and nature of fault movement in the San Fernando earthquake, U.S. Geol. Survey Prof. Pap. 733, 41-54.

Kahle, J.E. (1975). Surface effects and related geology of the Lakeview Fault segment of the San Fernando Fault zone, Calif. Div. Mines and Geol. Bull. 196, 119-135.

Melosh, H.J. (1983). Acoustic fluidization, Am. Scientist 71, 158-175. 
Melosh, H.J. (1996). Dynamic weakening of faults by acoustic fluidization, Nature 379, 601-606.

Nason, R.D. (1973). Increased seismic shaking above a thrust fault, San Fernando, California, Earthquake of February 9, 1971, 3, Washington, U.S. Dept. of Commerce,123-126.

Oakeshott, G.B., ed. (1975). San Fernando, California, Earthquake of 9 February 1971, Calif. Div. Mines and Geol. Bull. 196, 463 pp.

Oglesby, D.D., R.J. Archuleta, and S.B. Nielsen (1998). Earthquakes on dipping faults: The effects of broken symmetry, Science $\mathbf{2 8 0}$, 1055-1059.

Oldham, R.D. (1899). Report on the great earthquake of 12th June 1897, Geol. Survey India Mem. 29, 379 pp.

Richter, C.F. (1958). Elementary Seismology, San Francisco, W.H. Freeman \& Co., 768 pp.

Schallamach, A. (1971). How does rubber slide?, Wear 17, 301-312.

Sharp, R.V. (1975). Displacement on tectonic ruptures, Calif. Div. Mines and Geol. Bull. 196, 187-194.

Shi, B., J.N. Brune, A. Anooshehpoor, and Y. Zeng (in press). Dynamics of thrust faulting: 2-D lattice model, Bull. Seism. Soc. Am.

Shreve, R.L. (1966). Sherman landslide, Alaska, Science 154, 16391643.

Shreve, R.L. (1968). The Blackhawk Landslide, Geol. Soc. Am. Spec. Pap. 108, 47 pp.

Somerville, P., K. Irikura, R. Graves, S. Sawada, D. Wald, N. Abrahamson, Y. Iwasaki, T. Kagawa, N. Smith, and A. Kowada (in press). Characterizing earthquake slip models for the prediction of strong ground motion, Bull. Seism. Soc. Am.

Somerville, P.G., N.F. Smith, R.W. Graves, and N.A. Abrahamson (1997). Modification of empirical strong motion attenuation relations to include the amplitude and duration effects of rupture directivity, Seism. Res. Lett. 68, 199-222.
Wallace, R.E. (1984). Eyewitness account of surface faulting during the earthquake of 28 October 1983, Borah Peak, Idaho, Bull. Seism. Soc. Am. 74, 1091-1094.

Weeks, W.F. and Anderson, D.L. (1958). Sea ice thrust structures, $J$. Glaciology 3, 173-175.

Yomogida, K. and T. Nakata (1994). Large slip velocity of the surface rupture associated with the 1990 Luzon earthquake, Geoph. Res. Let. 21, 1799-1802.

Zeng, Y., B. Shi, and J.N. Brune (1996). Dynamic simulation of shallow angle thrust faulting [abstract], Eos, Trans. Am. Geophys. $U$. $77(46)$, F505.

Seismological Laboratory California Institute of Technology Pasadena, California (C.R.A.)

Seismological Laboratory University of Nevada Reno, Nevada (J.N.B.)

Pacific Gas and Electric Company San Francisco, California (L.S.C.)

California Division of Mines and Geology Los Angeles, California

(A.G.B.) 